\title{
The alla franca dandy; modernity and the novel in the late 19th-century Ottoman Empire
}

\section{Korhan Mühürcüoğlu}

To cite this article: Korhan Mühürcüoğlu (2018): The alla franca dandy; modernity and the novel in the late 19th-century Ottoman Empire, British Journal of Middle Eastern Studies, DOI: 10.1080/13530194.2018.1500271

To link to this article: https://doi.org/10.1080/13530194.2018.1500271

\section{Published online: 04 Sep 2018.}

\section{Submit your article to this journal 준}

Џll Article views: 101

View Crossmark data ¿ 


\title{
The alla franca dandy; modernity and the novel in the late 19th-century Ottoman Empire
}

\author{
Korhan Mühürcüoğlu (iD) \\ Department of Political Science and Public Administration, Bilkent University, Bilkent/Ankara, Turkey
}

\begin{abstract}
In the late 19th-century Ottoman novel, an iconic character draws attention: the alla franca dandy; a man who admires the Western culture to the point of mindless imitation, and who stands aloof from his own society as he condemns the Ottoman/Islamic culture in aesthetical terms. He was born out of the Ottoman intellectuals' ideas of and anxiety over Westernization, who sought to modernize the society without subverting the traditional foundations. As the Ottoman/Islamic and Western cultures collided, the alla franca dandy figure became the embodiment of Westernization gone astray and served the intellectuals' objective to educate the masses by setting a bad example to be avoided. However, though the alla franca dandy figure was brought forth, in this manner, to circumscribe the proper limits of modernization, he ironically evolved, through the novels of different authors, to express individualistic attitudes, and put forth a modernist critique of the Ottoman/Islamic tradition as the intellectuals' epistemological assumptions eroded and the society's present is questioned and problematized as in need of intervention.
\end{abstract}

In the Tanzimat ('Reforms') period (1839-1876) of the Ottoman Empire, we come across a certain Didon Arif in the Sublime Porte, an official who left the posterity such an odd soubriquet (Didon) as it was his usual practice to address his colleagues with the French phrase 'dis donc' ('say there') '; an eccentric figure whose mannerisms may at first sight seem to be personal idiosyncrasy of a man who was an admirer of the Western civilization. However, in the late 19th-century Ottoman Empire, the likes of Didon Arif, or francophiles, were no rarity. They inhabited and frequented the Europeanized Beyoğlu district of Istanbul and came mostly from the Ottoman bureaucracy, educated in Western-style institutions from Selim III's reign onwards. In the debates over the Ottoman Empire's Westernization, they had been either scapegoats blamed for many unwelcome intrusions from the West or laughingstocks derided for their absurd manner of behaviour by the intellectuals who were anxious to respond to Westernization properly without losing their Ottoman/Islamic culture. It is thus not curious that the francophile had found himself a prominent place within the Ottoman novel as well, as the Ottoman novel of this period was one of the venues in which

CONTACT Korhan Mühürcüoğlu $\otimes$ kmuhurcuoglu@bilkent.edu.tr $\Theta$ Bilkent University, Cukurambar Çankaya/ Ankara, Turkey

${ }^{1}$ Şerif Mardin, The Genesis of Young Ottoman Thought: A Study in the Modernization of Turkish Political Ideas (New York: Syracuse University Press, 2000), 210-211.

(c) 2018 British Society for Middle Eastern Studies 
social problems were discussed and Westernization was naturally a major theme. Ahmet Mithat Efendi was the first to transform that figure into a literary character in his novel Felatun Bey ile Rakım Efendi ('Felatun Bey and Rakım Efendi') of 1876 in which the Felâtun Bey figure appears; the first of all alla franca ${ }^{2}$ dandies, or francophiles, that were to dominate the Ottoman novel. Ahmet Mithat's example was soon followed by other novels with alla franca dandy protagonists; Recaizade Mahmut Ekrem's Araba Sevdası ('The Carriage Affair', published in 1898) and Hüseyin Rahmi Gürpınar's Şıpsevdi ('Quick to Fall in Love', published in 1911). The alla franca dandies of these novels were men of vanity and extravagance who foolishly squander their fathers' fortune on the French fashion of the day, amusements, gambling and on women as they immerse themselves in every imaginable reverie. They admire the Western civilization to the point of mindless imitation and feel almost hatred towards the Ottoman/Islamic culture. They are portrayed as superficial men who even do not have a proper idea of the Western culture they adore in the most nonsensical fashion.

How could one situate the alla franca dandy within a general debate on modernization, a modernization that branches out into an array of problems from cultural imperialism to identity politics? Or, how could one interpret that figure who mimics a foreign culture that he deems superior? Edward Said, in Culture and Imperialism, says that 'Never was it the case that the imperial encounter pitted an active Western intruder against a supine or inert nonWestern native; there was always some form of active resistance [... $]^{\prime 3}$ (italics in the original). Said, in this manner, reduces the relations between the Western and non-Western societies to a dichotomy of domination and resistance. In such a view, the alla franca dandy, seen as a critique of false Westernization, would simply be cultural resistance. Shaden M. Tageldin, as she argues against that position, says that 'Understanding cultural imperialism as willful imposition - not attractive proposition - the reigning discourse conceals the undertow of seduction, which often transmits colonial culture'. ${ }^{4}$ For Tageldin, cultural imperialism becomes truly effective in an unconscious manner, through what she calls 'translational seduction', in which the seducer represents itself as seduced in order to better seduce into subjection as in Napoleon's address to the Egyptian people written in Arabic and teeming with Islamic references that poses as admiration for the colonized culture. The colonized culture is thus lured into subjection. ${ }^{5}$

Tageldin is right in that, between the Western and non-Western societies, there is a relation of seduction as well, not just of domination and resistance. Though the alla franca dandy is another instance of seduction by Western culture, it differs from 'translational seduction' that is conceived within colonial relations and power-struggles and acts only towards subjection even though subjection is materialized in a non-violent manner. In the alla franca dandy's seduction by the Western culture, there is indeed a construction of an aestheticized utopian vision, almost independent from the political and social actualities of that culture, that acts as a liberating and modernizing current within the society. In other words, though Tageldin speaks of 'the more counter intuitive and less optimistic possibility that the "love" extended to the foreign [...] might more

\footnotetext{
${ }^{2 \prime}$ Alla franca,' derived from Italian, means 'French-style'; a phrase that is contrasted with 'alla turca,' meaning 'Turkish style.'

${ }^{3}$ Edward Said, Culture and Imperialism (New York: Vintage Books, 1994), xii.

${ }^{4}$ Shaden M. Tageldin, Disarming Words: Empire and the Seductions of Translation in Egypt (California: University of California Press, 2011), 7.

${ }^{5}$ Tageldin, Disarming, 17.
} 
deeply colonize than liberate'. ${ }^{6}$ I presume that such a possibility of liberation indeed exists despite the fact of an unequal relationship. To say that the Ottoman modernization (seen through the alla franca dandy figure) was seduction does not necessarily mean that the essential Western modernity seduced an accidental Ottoman modernization which nevertheless was only a distorted copy, or an imitation of the original model that claims to be universally applicable yet somehow eludes germination outside Europe and leads only to subjection. Though modernization itself is universal, the forms under which it appears are particular and the Ottoman modernization's particularity lies in its unique manner of encounter with the Western culture.

I contend in this article that the alla franca dandy character of the late 19th-century Ottoman novel was born out of the Ottoman intellectuals ${ }^{7}$ ideas of and anxiety over Westernization who sought to Westernize the society, but within a certain limit. These intellectuals, though of the opinion that Western political and economic institutions might be adopted, circumscribed the limits of a proper Westernization so as not to subvert the traditional, Ottoman/Islamic foundations of society. ${ }^{8}$ The alla franca dandy was thus there to show how Westernization should and should not be. However, in tandem with the Hamidian regime's (1876-1909) sociopolitical developments, that is, as the intellectuals withdraw from politics under repressive measures and begin to concentrate upon social matters, that archetypal figure ironically evolved into an awareness of the individual per se; the individual as a reference point, according to which the Ottoman/Islamic culture and tradition is questioned, criticized and re-evaluated, despite the fact that the alla franca dandy's raison d'etre was originally to thwart the anti-traditional currents within the Ottoman society. Yet, the alla franca dandy's critique of the Ottoman/Islamic culture was not a political or social criticism; it was a judgement of taste. As the Hamidian period's intellectuals problematized the present, they idealized the Western culture within aesthetical terms as a non-political, non-ideological and autonomous construct, or as the site of a utopian vision. The alla franca dandy, seduced by such utopian vision, expresses an aesthetical reaction to the Ottoman/Islamic culture found deficient, through a dichotomy of beautiful/ugly that condemns the Ottoman/Islamic culture as ugly and praises the Western culture as beautiful. The traditional values of the Ottoman/Islamic culture, faced with an aesthetical aversion, then came to be eroded and the vacuum created by that erosion was filled up with the autonomous, utopian individual who is (or, more correctly, who should be) in liberty. Marshall Berman says of the modernity of underdevelopment: '[...] where the process of modernization has not yet come into its own, modernism, where it develops, takes on a fantastic character, because it is forced to nourish itself not on social

\footnotetext{
${ }^{6}$ Ibid., 10.

${ }^{7}$ By 'Ottoman intellectuals', I mean not a well-defined group that endorsed a certain political ideology, but a group that consisted, in broad terms, of men-of-letters who were able to express their opinion to the public, without any reference to various political ideologies that they cherished. Yet, their concern with Westernization brings forth a fundamental commonality that binds that group coherently in their orientation.

${ }^{8}$ I owe the entire statement above to the works of Jale Parla and Nurdan Gürbilek. The idea of anxiety over Westernization, for instance, can be found in Parla's Babalar ve Oğullar in which the metaphor of becoming fatherless is expressive of much concerning the Ottoman intellectuals who tried to hold their ground in the face of modernization that threatened to cut off their roots within tradition. Gürbilek's article 'Dandies and Originals: Authenticity, Belatedness, and the Turkish Novel', on the other hand, is invaluable with regard to its emphasis on the Ottoman/Turkish intellectuals' attempts to unearth an original Turkish culture in vain as it was (and is) an impossibility in a modern society to preserve an insulated and local originality.
} 
reality but on fantasies, mirages, dreams. ${ }^{\prime 9}$ As I regard modernity as a problematizing of the present to arrive at an ideal state of affairs in the future (in Alev Çınar's sense ${ }^{10}$ ), or as a utopian vision (in Zygmunt Bauman's conception ${ }^{11}$ ); and as I define individualism as a translocation of truth from the eternal, omnipresent and omnipotent social and political institutions to the individuals themselves as they interpret their own experiences I contend that as we look closely at the three novels named above, we can see modernity had taken roots in the non-Western Ottoman society of the late 19th-century through a historical trajectory that is distinct from its European counterparts, yet ineluctably through an alternative path; a path on which the encounter with the Western culture has created a vision of ideal society and on which individualism has played a prominent role.

\section{The alla franca dandy archetype}

The alla franca dandy did not take the stage as a mouthpiece of the Ottoman ancien régime's custodians. From the reigns of Selim III (r. 1789-1807) and Mahmud II (r. 1808-1839) onwards, the Ottoman statesmen and intellectuals came to realize that the import of military technology was not enough in dealing with the problems and evils that beset the Empire and 'they began to realize that their assumptions were no longer absolute truths'. ${ }^{12}$ Such an awareness led the Ottoman elites to problematize the present as something deficient and in need of intervention. As Alev Çınar has stated in relation to the modernist projects of the Early Republic and the 1990s of Turkey, modernity is both a 'construction of the present as deficient ${ }^{13}$ and an attempt at 'transformation for a better future'. ${ }^{14}$ Surely, the Ottoman Empire of the late 19th century was still traditional, resting on the millet system that compartmentalized the society along ecclesiastical demarcation lines as Muslims, Orthodox Greeks, Jews, etc. Yet, the secular reforms to resuscitate the state had loosened the grip of Ottoman ancien régime's epistemological certainties and made it possible to survey the changes in political and social matters through the perspective of progress; a perspective that necessitates a certain relation to the present perceived of as a boundary between the past and the future. Such a reorientation brought about an ambivalent attitude towards political and social developments, an ambivalence that is truly modern in its tension between the anxiety to preserve the order of things and the desire to improve upon the prevailing conditions that are seen unfavourable. As Marshall Berman says of modern

\footnotetext{
${ }^{9}$ Marshall Berman, All That Is Solid Melts Into Air: The Experience of Modernity (London: Verso, 2010), 235-36.

${ }^{10}$ Çınar defines her conception of modernity briefly as follows: '[...] modernity is understood here as an intervention related to bodies, space, and time that constructs their present as corrupt in order to induce a need for transformation toward a better future.' Alev Çınar, Modernity, Islam, and Secularism in Turkey: Bodies, Places, and Time (Minneapolis: University of Minnesota Press, 2005), 7-9.

${ }^{11}$ Bauman's idea of utopia expresses what I take to be the modernist attitude in this article, that is, a problematizing of the present and a desire to reach an ideal state of affairs in the future: 'To be born, the utopian dream needed two conditions. First, an overwhelming (even if diffuse and as yet inarticulate) feeling that the world was not functioning properly and was unlikely to be set right without a thorough overhaul. Second, the confidence in human potency to rise to the task, a belief that "we, humans, can do it," armed as we are with reason which can spy out what is wrong with the world and find out what to use in replacing its diseased parts, as well as an ability to construct the tools and weapons required for grafting such designs onto human reality.' Zygmunt Bauman, Liquid Times: Living in an Age of Uncertainty (Cambridge: Polity Press, 2007), 98.

${ }^{12}$ Niyazi Berkes, The Development of Secularism in Turkey (New York: Routledge, 1998), 25.

${ }^{13}$ Çınar, Modernity, 7.

${ }^{14}$ Ibid., 9.
} 
individuals: 'They are moved at once by a will to change - to transform both themselves and their world - and by a terror of disorientation and disintegration, of life falling apart. $^{15}$ That 'will to change' and that 'terror of disorientation' were the defining features of the modern Ottoman novel as well, a synthesis of traditional and antitraditional in their ambivalent tension. Ahmet Ö. Evin says that

The early popular novelists, looking for a synthesis of Western civilization and Turkish culture, borrowed elements from the meddah stories that reflected Turkish cultural values and placed them within the framework of the novel, a genre whose form for them represented an achievement of Western civilization. ${ }^{16}$

'The framework of the novel' is the realistic novel of 19th-century Europe. As Auerbach says, realism in that literature was a description of ordinary individual experiences within a contemporary, shared social milieu and time, a time that is not static or absolute as in Walter Benjamin's 'messianic time' but seen in its historical development. ${ }^{17}$ While the meddah tradition reflected the Ottoman/Islamic values and provided techniques, themes and plot structures, the realistic framework was an expression of anti-traditional currents as it concentrated on the individuals' experiences within a problematic society and not on the classical Ottoman subject-matters like divine and eternal love. In other words, the 'terror of disorientation,' or that desire to preserve the Ottoman/Islamic culture found a proper means in the meddah figure. Meddahs were an integral part of the Ottoman urbanism, storytellers who personified, mimicked and ridiculed the various archetypical figures like the Jew, the Armenian, etc. in their daily life settings to entertain the crowds gathered in coffee houses and to draw a few moral lessons as they mocked human folly. The meddah tradition, in this sense, was a disciplinary mechanism found convenient to struggle with cultural disintegration: '[...] ridicule has a universal role in the maintenance of social order. ${ }^{18}$ In a desire to change, that disciplinary mechanism, framed within the paradigms of the Western realistic novel, was transformed into a progressivist means to effectuate change in the cultural domain while not disturbing the balance between tradition and social change. The alla franca dandy was thus the product of a modernist attitude that problematized the present to reach an ideal state of affairs in the future in which a 'proper' Westernization would be achieved within an Ottoman/Islamic culture: an alternative path to modernity. In this sense, the alla franca dandy sets a negative example to show how Westernization should and should not be.

If we look for what is common to all the novels named above, it would be seen that they are the products of Ottoman intellectuals' ideas of and anxiety over Westernization and that they are all satires. The novels are all about Westernization since the Ottoman intelligentsia had assumed the role to educate the masses and addressed what they believed to be the most urgent matter, namely, Westernization and its possible consequences: 'In the Tanzimat novel, the author's didactical and interpretative tone of voice constantly intervenes in the narrative. ${ }^{19}$ They are all satires as the alla franca dandy's example was intended to serve as a social correction mechanism in Bergson's

\footnotetext{
${ }^{15}$ Berman, All That Is Solid Melts Into Air, 13.

${ }^{16}$ Ahmet Ö. Evin, Origins and Development of the Turkish Novel (Minneapolis: Bibliotheca Islamica, 1983), 32.

${ }^{17}$ Kader Konuk, East West Mimemis: Auerbach in Turkey (California: Stanford University Press, 2010), 181-189.

${ }^{18}$ Michael Billig, Laughter and Ridicule: Towards a Social Critique of Humour (London: SAGE Publications, 2005), $201-2$.

${ }^{19}$ Jale Parla, Babalar ve Oğullar: Tanzimat Romanının Epistemolojik Temelleri (İstanbul: İletişim Yayınları, 1990), 60. My translation.
} 
sense of the term, to condemn the lesser evil of snobbism through mockery before it becomes a chronic disease and too serious a matter to be treated in a comical manner. It is worth noting in this regard that before 1876, the year in which Ahmet Mithat's novel was published, there were not any novels that recognizably have alla franca dandy characters. This is not surprising since the Ottoman novel genre itself in its realistic framework was not much older than the alla franca dandy himself. In the years preceding and following the First World War (1914-18) and the Turkish War of Independence (1919-22), however, the alla franca dandy loses comicality and becomes the alla franca traitor as Berna Moran has demonstrated; a figure that collaborates with the invasion forces and who poses too serious a threat to be taken lightly. Yakup Kadri Karaosmanoğlu's Sodom ve Gomore ('Sodom and Gomorrah') of 1928, for instance, depicts Istanbul in the aftermath of its invasion, a city where alla franca Turks collaborate with the invasion forces to fill their pockets and who have no comicality. The comical alla franca dandy figure is, in this regard, the offspring of a more cosmopolitan phase of the Ottoman Empire before the two wars fostered strong nationalistic sentiments.

Yet, it would be a mistake to lump all the alla franca dandies together as if they were exact copies of each other and to treat those characters as a simple variation over the same theme of Westernization gone astray. It is true that whom we call the alla franca dandy is a man of appearances, a superficial character. However, that superficiality should not be seen in a superficial manner. For instance, Moran, who otherwise is quite perceptive and who gives us the first elaboration of the figure, takes the alla franca dandy's superficiality at its face value, as a critique of snobbism in false Westernization. This is valid only with regard to Ahmet Mithat's Felâtun Bey and he misses the individualistic tendencies developing across the three figures. Mardin, on the other hand, whose article on super-Westernization is of much value, does not take the alla franca dandy figure as any more than a critique of conspicuous consumption that was introduced into the Ottoman economy after the Tanzimat Edict of 1839. For Mardin, conspicuous consumption embodied in the alla franca dandy had disrupted the traditional social hierarchies as the Edict guaranteed private property and paved the way for capitalistic development. ${ }^{20}$ Though Mardin's view of the alla franca dandy explains much concerning the disruptive and anti-traditional currents within Ottoman modernization, his conception of that figure is static and relies totally on its disciplinary functions. Jale Parla and Nurdan Gürbilek, among the scholars who paid attention to the alla franca dandy figure, stand as exceptions; Parla, as she moves beyond the theme of false Westernization in snobbism and brings forth the epistemological problems of a modernizing society reflected in those foppish characters' falterings and Gürbilek, as she elaborates upon the identity crisis inherent in the figure in question. (I return to these views below.) Adding on the works of all those scholars, I draw attention to the gradual development of individualism that is to be seen in the alla franca dandy archetype.

Ahmet Mithat's Felatun Bey ile Rakım Efendi, which stands at the origin of this development, is an attempt at circumscribing the limits of Westernization; in

\footnotetext{
${ }^{20}$ Şerif Mardin, 'Super Westernization in Urban Life in the Ottoman Empire in the Last Quarter of the Nineteenth Century', in Turkey: Geographic and Social Perspectives, eds. Peter Benedict, Erol Tümertekin and Fatma Mansur (Leiden, E. J. Brill: 1974), 412-413.
} 
Kadıoğlu's words, an attempt in which a proper balance between 'the materialism of the West and the spirituality of the East ${ }^{\prime 21}$ would be struck to satisfy both the need of change and maintaining order. Ekrem's Araba Sevdası, however, is not concerned with circumscribing a proper Westernization. It rather is an elaboration upon the experience of Westernization itself. Ahmet Mithat condemns his Felâtun Bey's behaviour as a moralist and thereby elaborates upon his own ideal of Westernization in a didactic manner. Ekrem, on the other hand, seems to withdraw from the scene and portrays his alla franca Bihrûz Bey with the minutest details of his personality, his perplexity in the face of a crumbling ancien régime and, though he derides Bihrûz Bey's absurd manner of life, does not condemn him morally. ${ }^{22}$ With the publication of Araba Sevdası, we therefore see for the first time that the individual per se gains importance and becomes an object of anxious attention. Araba Sevdası, therefore, marks the second phase of this development. Hüseyin Rahmi Gürpınar's Şıpsevdi, which offers us the third and the final step of this development, is a recognition of the individual's importance against tradition. The alla franca Meftûn Bey is a man who ruthlessly criticizes the society and becomes his author's mouthpiece in disguise. ${ }^{23}$

\section{A balance between the materiality of the West and the spirituality of the East}

Felatun Bey ile Rakım Efendi's story is of two gentlemen who lead completely different lives. Felâtun Bey is a man of vanity and pomposity who squanders his father's fortune on the latest French fashion and on every imaginable kind of amusement; a man who admires, even worships, the Western civilization though he does not have any inkling of what that civilization is; an eccentric figure, an outcast, that feels an aversion towards his own Ottoman/Islamic culture. Ahmet Mithat portrays him as a man enamoured of his appearance:

Let us tell that much that he owned several hundreds of those pictures, painted on cardboards, that you can see in Beyoğlu's tailor shops showing the fashion of the day and Felâtun Bey, one of these pictures in hand, would study them before the cheval glass until he could bring out a perfect similarity between his own appearance and these pictures. ${ }^{24}$

As Frantz Fanon's Antillean 'embraces white culture, white beauty, white whiteness' ${ }^{25}$ in his inferiority complex, Felâtun Bey embraces Beyoğlu's European taste and finds satisfaction in the cheval glass that reflects his European image back to himself, distancing him from the Ottoman/Islamic culture that he sees as 'vulgar Turkishness'. ${ }^{26}$ Rakîm Efendi, on the other hand, is a man of morality who cherishes the Ottoman/Islamic

\footnotetext{
${ }^{21}$ Ayşe Kadıoğlu, 'The Paradox of Turkish Nationalism and the Construction of Official Identity', Middle Eastern Studies 32, no. 2 (1996): 180.

${ }^{22}$ Gürbilek says that Araba Sevdası fails to be a satire as 'The writer is no longer the guardian of the true self, since language itself does not work.' Nurdan Gürbilek, 'Dandies and Originals: Authenticity, Belatedness, and the Turkish Novel', The South Atlantic Quarterly 102, no. 2/3 (2003): 612.

${ }^{23}$ I owe this idea of Meftûn Bey as Gürpınar's disguised mouthpiece to Moran. See: Moran, Türk Romanına, 147.

${ }^{24}$ Ahmet Midhat Efendi, Felatun Bey ile Rakım Efendi (İstanbul: Özgür Yayınları, 2014), 31-2. All the translations from this novel are mine.

${ }^{25}$ Frantz Fanon, Black Skin, White Masks (New York: Grove Press, 2008), 45.

${ }^{26}$ Ahmet Midhat Efendi, Felatun Bey, 105-6.
} 
cultural values pretty much as Ahmet Mithat himself for whom he serves as a mouthpiece; an industrious man who earns his living by his own efforts.

Felatun Bey ile Rakım Efendi's story unfolds on two levels that develop in parallel. Though Felâtun Bey's person is gripping in his idiosyncrasy, his story is nothing besides a portraiture. Indeed, when Ahmet Mithat talks about Felâtun Bey or his similarly alla franca father Mustafa Merakî Efendi, his style begins to betray a penchant for the meddah tradition (addressing the audience directly, asking and replying to questions) and its mocking tone of voice: 'Our Mustafa Merakî Efendi was an alla franca kind of man. Do you know, besides, of which alla franca kind he was? Were not there those alla francas, fifteen or twenty years ago, in Istanbul? He was, you see, one of those. ${ }^{27}$ Ahmet Mithat tells that Felâtun Bey strolls in the famous promenades and trysts of Istanbul where ladies who die of boredom and gentlemen who seek affairs change letters and shop in the Europeanized Beyoğlu district. He frequents a theatre to visit a French actress named Polini (who bleeds him white), makes the acquaintance of an English family to whose cook woman he makes advances and disgraces himself. Felâtun Bey, in the end, repents and promises his friend Rakîm Efendi to amend his ways as he goes bankrupt at a gambling table (as he falls prey to a trick played against him by his beloved mistress Polini and her corrupt accomplices). He, then, finds a job in a government post in one of the Mediterranean islands and bids farewell to Istanbul, saying that he will now work honestly to pay his debts. Rakîm Efendi's story is wealthier in dramatic content; yet, as the story becomes a moral lecturing, quite insipid compared to Felâtun Bey's story. Rakîm Efendi is left an orphan at an early age and is raised by his devoted nanny who works hard for Rakîm Efendi's good. Rakîm Efendi, not disappointing her, becomes a self-taught man who mastered Ottoman language and literature and speaks French fluently as well. He makes translations from French to earn his living and gives Turkish lessons to an English family's daughters for extra income. As Ahmet Mithat portrays him, a kind of entrepreneur who cherishes an esnaf (artisan) morality in daily affairs. He buys a slave girl, Canan, who would later become his wife and though he had an affair with a French pianist named Yozefino and despite the advances of the English family's daughter, he does not corrupt morally and poses a model to be emulated by everyone; the true Ottoman gentleman of morals.

Ahmet Mithat's novel is not properly a modern, realist novel; that is, the novel gives priority to the plot, and not to the individuals themselves to bring them forth in their development as characters; a formal realism, at best, in Watt's sense of the term. ${ }^{28} \mathrm{~A}$ realistic novel, for Evin, must have the following traits: (1) 'a distancing on the part of the writer from his work'; (2) 'a sufficiently detached outlook on life enabling the writer to treat contemporary life and manners without feeling compelled to editorialize on the moral constitution of society'; and (3) 'the maintenance of as impersonal an approach as possible toward the characters presented so that characterization is not inhibited by the prejudice of the author. ${ }^{29}$ Similarly, Parla does not see realism, or an observation of an

\footnotetext{
${ }^{27}$ Ibid., 26-7.

${ }^{28}$ For Watt, formal realism is: '[...] the premise, or primary convention, that the novel is a full and authentic report of human experience, and is therefore under an obligation to satisfy its reader with such details of the story as the individuality of the actors concerned, the particulars of the times and places of their actions, details which are presented through a more largely referential use of language than is common in other literary forms.' lan Watt, The Rise of the Novel (London: The Bodley Head, 1957), 32.

${ }^{29}$ Evin, Origins, 173-4.
} 
individual's psychology in such more romantic works that believe in the value of certain sentiments. $^{30}$ These sentiments derive their value mostly from a sublimation of the Ottoman Empire's past. There is no detached or impersonal outlook in Ahmet Mithat, but much commentary on Felâtun Bey's morality. Though he says that 'Our intention here is not to vilify Felâtun Bey, but to deservedly familiarize the reader with his manner of life' he does the opposite and adds: 'Therefore, let us add that, though our Felâtun Bey may appear to be magnificent with regard to his richness and his complete selfconfidence (that is, his arrogance in common parlance), Felâtun Bey's situation was the contrary of that. ${ }^{31}$ In another passage, when Felâtun Bey and Rakîm Efendi accuse each other of being jealous and prodigal respectively, Ahmet Mithat asks: 'Which one do you approve of these two opinions?' And adds: 'We approve of Rakîm's.' ${ }^{\prime 32}$ Therefore, when Felâtun Bey falls in comical situations, we laugh at a man who deserves his just punishment:

Truthfully, Felâtun dances well. He dances without ever bending like a candle, since the pants he wears are quite tight and does not allow him much. During the dance, as he stepped on Margrit's foot and tried at once to pull himself together, a riping sound is heard from his behind. ${ }^{33}$

It is as if Felâtun Bey's alla franca tight pants and his infatuation with the European culture can endure just the same amount of tension, after which the tight pants are torn apart and his pretension of being European is spoiled, one with a single false step and the other with the reader's laughter, showing Felâtun Bey's underwear and his ridiculous soul simultaneously in their nakedness. Ahmet Mithat's mockery thus becomes a moral judgement.

Mockery without moral judgement was unthinkable for Ahmet Mithat as it would necessitate a detached, impersonal attitude towards the Ottoman/Islamic culture. Such attitude, then, would threaten the reader's belief in the Ottoman/Islamic culture's unquestionable norms as an observation of Felâtun Bey's psychology might cause alternative interpretations. Indeed, even Ahmet Mithat's romantic vision of the Ottoman/Islamic culture is not firm enough and needs a Westerner's confirmation. When Rakîm Efendi arranges for a short trip, he invites the French pianist Yozefino as well. They sail with a boat across the Bosphorus and settle in a calm quarter. Yozefino, as if enchanted, begins to praise the nature around and the Ottomans who know to see such beauties: 'By jove, I am very pleased right now. Rakîm, should I tell you the truth? Turks are, in any case, better than Europeans! ${ }^{34}$ Following that enthusiastic praise, Yozefino complains about the monotonous and insipid social life and insincerity of Europeans. In the romantic landscape of the Bosphorus, consecration is thus made by the hands of a European, a scene which was certainly not similarly enacted in the international stage.

Ahmet Mithat's novel has, in this regard, rather an allegorical tinge and the characters play strictly predetermined roles assigned to them in a plot that preaches a political

\footnotetext{
${ }^{30}$ Parla, Babalar, 63.

${ }^{31}$ Ahmet Midhat Efendi, Felatun Bey, 30.

${ }^{32}$ Ibid., 113.

${ }^{33}$ Ibid., 80.

${ }^{34}$ Ibid., 127-8.
} 
position. Both Felâtun Bey and Rakîm Efendi serve as proxies for the Ottoman society, or for two sociopolitical potentialities that Ahmet Mithat thought to be inherent in the late 19th-century Ottoman society. On the one hand, a Westernization 'gone astray' embodied in Felâtun Bey's person that symbolizes the disintegration of the Ottoman/Islamic culture and tradition that has, so far, tightly regulated the Ottoman political and social practices. On the other hand, a modernization that strikes a balance between 'the materialism of the West and the spirituality of the East' in Kadıoglu's formula, a balance expressed through Rakîm Efendi's ability to sustain Ottoman/Islamic morals along his entrepreneurial inclinations. Ahmet Mithat's attempt at synthesizing 'the materialism of the West and the spirituality of the East' is a modernist project in that it problematizes the present as something deficient, as in need of intervention and aspires towards a future society in which Rakîm Efendi's 'spirituality', that is, his Ottoman/Islamic moral values would be in harmony with the 'materialistic' values of an entrepreneur.

In this regard, Ahmet Mithat's Felatun Bey ile Rakım Efendi is to be seen as an apologetics of the Ottoman/Islamic culture that envisaged a modernization that was neatly circumscribed within the confines of technical improvement in production processes. $^{35}$ Any transgression of the limit is deemed undesirable and snobbish, an alienation from one's own culture and a fall into inauthenticity. Felâtun Bey is, therefore, mocked and morally condemned as a laughingstock of a satire that clearly functions as a social correction mechanism. As Vladimir Propp says concerning the popularity of humorous and satirical literature in Russia: 'Our society supports them because they represent satirically all the flaws of our daily life that we have not eliminated but that art helps us eradicate. ${ }^{36}$ Felâtun Bey's person embodies a transgression, an unbalance where Westernization goes astray and becomes excessive as it leaves the secure domain of 'materiality' and begins to erode the local culture gradually. For Ahmet Mithat, such a transgression should be corrected through any means available and the community is above the individual in such a perspective. Ekrem's Araba Sevdası offers the reader a completely different picture of Westernization.

\section{The emergence of the individual}

When Araba Sevdası was published in 1898, after the manuscript had laid dormant for many years on Ekrem's desk, ${ }^{37}$ the second step of the alla franca dandy's development was taken. With that novel, the alla franca dandy was not merely a puppet of an ideological claim any more. Though Bihrûz Bey is a replica of the alla franca dandy archetype in externals, his story offers the reader a completely different account of that character's personality: a reflection upon an individual's inner experiences within a disoriented society. The story begins as Bihrûz Bey, together with his mother and servants, moves to a kiosk in Çamlıca to pass his summertime there, with an intention

\footnotetext{
${ }^{35}$ Though Ahmet Mithat's vision of Westernization was limited to technical improvement of the economic conditions prevalent in the late 19th-century Ottoman Empire, it does not mean that such a view completely eschews any cultural change as Ahmet Mithat clearly admits of a need for a change, for instance, in the working habits of the Ottoman subjects.

${ }^{36}$ Vladimir Propp, On the Comic and Laughter (Toronto: University of Toronto Press, 2009), 149.

${ }^{37}$ The novel was written in 1889 , but could only find a chance to be published in 1898 .
} 
to visit popular promenades of the district. He often visits Çamlıca Public Garden to show himself off to the high society there who rushes to the garden at every opportunity. As Ekrem says: 'Wherever Bihrûz Bey goes, wherever he is, his intention is not to see while being seen, but only to be seen. ${ }^{38} \mathrm{He}$ adds: 'When he came to Istanbul, he was keen on three things: first, driving carriages; second, being more pompous than all the alla franca gentlemen; and third, speaking with barbers, shoemakers, tailors and waiters in French. ${ }^{39}$ Bihrûz Bey seeks 'only to be seen' and seen in a certain manner, that is, as European: a 'man without content', in Agamben's words, who is 'condemned to depend on something other than himself' ${ }^{40}$ and finds 'his own essence precisely in the inessential, his content in what is mere form'. ${ }^{41}$ In other words, Bihrûz Bey is the beautiful semblance of a European.

In one of his routine hikes around the garden, he chances upon a lady with whom he at once falls into love, mistaking the lady for a gentlewoman from the upper-class families (who, in fact, is a woman of ill-repute.) Bihrûz Bey, then, pays an enthusiastic visit to his French mentor Mösyö Piyer, wishing that his mentor would adorn the story with poetic expressions: 'Bihrûz Bey, as he would listen to these words, would be honoured and delighted as he would think himself the hero of this beautiful and poetic romance. ${ }^{42}$ Bihrûz Bey's life thus becomes an imitation of art $^{43}$ and his desires begin to be mediated by the French romances he reads. He writes a love letter for the lady, but succeeds only to produce a blather, a melange of Ottoman-Turkish and French words with a poem appended that was terribly translated as he only has a superficial command of both Ottoman and French. In his next visit to the garden, he throws the love letter into the lady's landau, but the letter would be never read. He gets demoralized as the lady never contacts him and goes through his love letter to see whether anything is wrong with what he wrote. He notices to his astonishment that he addressed, unawares, the lady in the most unbecoming way as he translated the poem wrongly. He hears of the lady's death (which is a lie) and thinks that her death was because of his insulting love letter, becomes utterly melancholic and sodden with grief. In the final scene, he runs into the lady and his world of illusions shatters as he at last recognizes the lady's true identity and loses his romantic pleasure in sadness that he imitates from French romances. Araba Sevdası, in short, is a story in which Westernization disarrays one's perception of reality.

Ekrem, unlike Ahmet Mithat, does not directly interfere in the narrative to condemn or praise his character's deeds as he seems to renounce the fatherly role to educate the masses. Araba Sevdası, in this regard, satisfies Evin's criteria of realism (distancing from the work, absence of moral judgement and an impersonal attitude). In other words, Ekrem shifts attention from morality to the loss of meaning in a disoriented society. ${ }^{44}$ For instance, to append a poem to his love letter, Bihrûz Bey opens the poet Vâsıf's

\footnotetext{
${ }^{38}$ Recaizade Mahmut Ekrem, Araba Sevdası (Eleştirel Basım) (İstanbul: İletişim Yayınları, 2014), 55. All the translations from this novel are mine.

${ }^{39}$ Ekrem, Araba Sevdası, 54.

${ }^{40}$ Giorgio Agamben, The Man Without Content (Stanford: Stanford University Press, 1994), $22-4$.

${ }^{41}$ Agamben, The Man, 54.

${ }^{42}$ Ekrem, Araba Sevdasi, 96-7.

${ }^{43}$ Robert P. Finn talks about 'the curious state of life imitating art' concerning Bihrûz Bey. Robert P. Finn, The Early Turkish Novel: 1872-1900 (Istanbul: The ISIS Press, 1984), 68-9.

${ }^{44}$ For loss of meaning in Araba Sevdası, see Parla's and Gürbilek's works cited in this article.
} 
Divân and, in one of his poems, comes upon the word 'siyeh-çerde'. He consults Lügat-i Osmaniye ('Ottoman Dictionary'), the French dictionary 'Biyanki' and the Turkish dictionary Redhouse many times and, in the end, mistakes a similar word for the word he actually looks for. He decides that the word must mean 'a blonde' and finishes the letter where he addresses Perîveş Hanım as 'siyeh-çerde'. As is related above, Bihrûz Bey begins to suspect that there is perhaps something wrong with his letter as the lady never responds. He inquires after the word's ('siyeh-çerde') meaning in the office and learns that he used a most inconvenient word to be said to a decent woman:

- Bihrûz Bey: What have you understood from 'Bir siyeh-çerde civandır?'

- Nâim Efendi: Does not that mean a handsome, swarthy young man?

- Bihrûz Bey: Who?

- Nâim Efendi: How do I know? We should ask the deceased Vâsıf for that ... ${ }^{45}$

In despair, Bihrûz Bey's thoughts become chaotic:

What the hell am I going to do now? ... How to find an excuse? ... What a brutishness! ... She must have been faşe [angry] ${ }^{46} . .$. El a rezon! ... [She's right.] 'Bir siyeh-çerde,' God damn you! ... Could not that poet [poet] find another nonsense but that? ... Oh! ... Oh! ... What should I do now? ... Kom jö süi bet! ... [How stupid I am!] [...] Could such impertinence be expected from Redhouse? ${ }^{47}$

As though Bihrûz Bey's words have no referents in reality, his utterances end up being absurdities when communicated outside the world of French romances. Even when Bihrûz Bey is not absurd, he is necessarily misunderstood. Morality, understood as an attempt at giving meaning to social phenomena, is beyond Bihrûz Bey's reach. Bihrûz Bey thus becomes comical in his absurdity, but not condemned morally. As Moran has discussed at length, Ekrem utilizes the stream-of-consciousness technique for the purpose in which Bihrûz Bey's thoughts are presented naturally as disconcerted, yet somehow connected, series of ideas and images. ${ }^{48}$ With such a technique, Ekrem manages to portray how Westernization might influence an individual's perception and experience of reality, without relying on normative value judgements interfering in-between the lines. Bihrûz Bey, in this sense, does not set a bad example to be avoided, but an individual character who has similar experiences with the reader himself. As Berna Moran says of that character: 'To understand is to forgive. ${ }^{49}$ Ekrem, the reader, and the Bihrûz Bey figure thus form a kind of community who shares similar experiences. Erich Auerbach, in a lecture, gives the following account of the realist novel: 'So, a realist novel must be contemporary in such a way that the reader understands its subject to be a part of the life which shares a commonality with his own experience [...]. ${ }^{50}$ Ekrem's Araba Sevdası, in this sense, is the first step towards realism and he, in this way, brought the individual to the fore in his development and enabled himself to better elaborate upon the Ottoman Empire's Westernization and its influences upon the society.

\footnotetext{
${ }^{45}$ Ekrem, Araba Sevdası, 178-80.

${ }^{4}$ Italicized words are French words written phonetically as in Turkish.

${ }^{47}$ Ekrem, Araba Sevdası, 181-2.

${ }^{48}$ Moran, Türk Romanına, 84.

${ }^{49}$ Ibid., 318. The translation is mine.

${ }^{50}$ Konuk, East, 182.
} 
Ekrem's Araba Sevdası, as was said, does not grapple with the task of circumscribing the limits of a proper Westernization. The novel rather interrogates the individual's experience of Westernization as Ekrem looks into that experience without anchoring the narrative in preordained truths and political objectives. The Bihrûz Bey satire, in this sense, is not framed within the bounds of the epistemological certainties of the Ottoman/Islamic culture and does not function as Ahmet Mithat's social correction mechanism. Bihrûz Bey, in other words, is not mocked from the high position of a lofty morality whose truth is not doubted. ${ }^{51}$ On the contrary, Araba Sevdası, as Jale Parla pointed out, questions those epistemological certainties:

It seems that, with that novel, the presence of two incompatible epistemological systems was recognized for the first time and the possible confusion that might result from that duality was pointed out. Besides, Araba Sevdası is a textual questioning of these two opposing epistemological systems and a negation of the idea that these systems can exist side by side. ${ }^{52}$

The late 19th-century Ottoman Empire, through a cycle of reforms and counter-reforms (in the form of reinvented traditions ${ }^{53}$ ), had come to have a bifurcated culture in which two different weltanschauungs collided. ${ }^{54}$ Bihrûz Bey is a product of this collision through which all kinds of incongruities pervade the society. Indeed, Daryush Shayegan's Cultural Schizophrenia asks what Ekrem was trying to do in his novel: 'How does a person adapt to a world in which two such different models are facing each other, without running the risk of falling into absurd behaviour ${ }^{\prime 55}$ Ekrem's Araba SevdasI rejects that such an adaptation 'without running the risk of falling into absurd behaviour' is possible as Bihrûz Bey is portrayed as a man whose admiration for the Western culture (without the cultural basis that lay behind) produces nothing but comical scenes and absurdities. As Propp says: '[...] any feature or oddity that distinguishes a person from his or her environment can make that person funny. ${ }^{156}$ Ekrem, in this regard, brings the individual per se to the fore as he looks into a society in which epistemological certainties erode as they impair the local, Ottoman/Islamic culture. In other words, the anxiety of this disorientation makes the individual who suffers that condition the centre of attention.

Araba Sevdası, in this regard, might be read as a critique of Ahmet Mithat's vision of Westernization as a balance between the materialism of the West and the spirituality of the East. Ahmet Mithat was of the opinion that it is possible to adopt a few techniques from the Western civilization without the cultural foundations that lay behind them.

\footnotetext{
${ }^{51}$ Nurdan Gürbilek says: 'What makes The Carriage Affair unique among Tanzimat novels, what makes it something more than a document of the "Bihruz syndrome," is not its being a satire leaning on communitarian values, but rather its failure to be a satire. In satire there is an insurmountable wall, an unsurpassable boundary between the false other and the true self, and it is by mocking the false other that the writer ensures the true self ... There is neither a firm narrator nor a resolute authorial voice in the novel to denounce the foppish Bihruz. It is rather a hesitant, faltering, and undecided voice that we find there ... a voice that does not differentiate itself from that of the mocked character.' See: Gürbilek, 'Dandies and Originals', 612.

${ }^{52}$ Parla, Babalar, 121 . The translation is mine.

${ }^{53}$ For those re-invented traditions, see: M. Şükrü Hanioğlu, A Brief History of the Late Ottoman Empire (New Jersey: Princeton University Press, 2008), 127-128.

${ }^{54}$ For the bifurcated culture of the late 19th-century Ottoman society, see: Hanioğlu, A Brief History, 53 and Berkes, The Development, 109.

${ }^{55}$ Daryush Shayegan, Cultural Schizophrenia: Islamic Societies Confronting the West (New York: Syracuse University Press, 1997), 50.

${ }^{56}$ Propp, On the Comic, 40.
} 
Shayegan criticizes the view that can also be found in the post-revolutionary Iran of the 1980s, a critique that defines Ekrem's stance in Araba Sevdası as well:

As a final illusion, we formed the conviction that it would be possible to be selective with the nature of the things we were obtaining: to separate the wheat from the chaff, to choose technology and firearms while heroically ruling out the subversive, laicizing ideas which lay behind them. ${ }^{57}$

It is not possible 'to separate the wheat from the chaff' as a culture is a composite body that does not admit of any dissection save in theoretical analysis and whose material culture and development cannot be detached from the epistemological assumptions that underlie them. In other words, any venture to synthesize the two distinct epistemologies that lay behind, for instance, the Ottoman/Islamic and Western cultures results, in Shayegan's words, in a 'mutilated consciousness'; a consciousness in which the two cultures can only deform each other and out of which nothing but absurdities come. As Nurdan Gürbilek says: 'Hence the double deformation: the local self will cause the foreign ideal to appear as a deformed one, while the foreign ideal has already deformed that local self. ${ }^{58}$ Ekrem's Araba Sevdası, in this regard, narrates the story of a man with mutilated consciousness who suffers from the mutual deformation of two epistemologies and he becomes, to the same extent, an absurd man and a subject of comedy.

If we consider the political and social atmosphere of Ekrem's time, Araba Sevdası's meaning would be better understood. The reign of Abdülhamid II (r. 1876-1909), who was named Kızıl Sultan ('The Red Sultan'59) by his opponents, was a reactionary and oppressive period in which any opposition to the sultan's autocracy was subject to, at the very best, strict censorship. As the Ottoman intelligentsia of this period passed through the autocratic measures of the regime, that is, through imprisonment, exile and censorship, they retreated, in Isaiah Berlin's words, into their 'inner citadels' and began to concentrate on social matters per se instead of political subject matters proper. The Hamidian period, for that matter, is to be best described as a period of ironies since the intellectuals' interest in social matters opened up new vistas and accelerated the spread of Western ideas. ${ }^{60}$ Such an interest in social matters had brought the individual to the fore as social institutions like prearranged marriages had come to be questioned through the individual's perspective who suffers its undesirable outcomes. The term 'utopian individualism' that Niyazi Berkes coined, but not elaborated upon, would be of much avail in understanding the period in this regard. Berkes uses the term specifically for the authors who gathered around the literary review Servet-i Fünûn ('The Treasure of Sciences'), a journal of the Edebiyat-ı Cedide ('The New Literature') movement and Ekrem was the leading figure in the movement. Their individualism was 'utopian' in that they regarded the Western civilization almost as a work of art to be contemplated aesthetically; a civilization that represents an epitome of perfection in which the

\footnotetext{
${ }^{57}$ Shayegan, Cultural, 150.

${ }^{58}$ Gürbilek, 'Dandies and Originals', 603.

${ }^{59}$ The adjective kızıl ('red') was a pejorative reference to Abdülhamit II's violent means in dealing with the subjects of the Empire.

${ }^{60}$ For the ironies of the period and the intellectuals' concern with social matters, see: Berkes, The Development, 276 and 289.
} 
individual per se is of utmost importance as the harbinger of all values, and in which there reigns perfect harmony and liberty:

They aspired for the life of the European individual in which material comfort, scientific progress, and individual liberty reigned - not for a society criticized for its class inequalities, its crimes and prostitution, its greedy money-makers and exploited proletariat. ${ }^{61}$

It is for this reason that Ahmet Mithat criticizes Ekrem that he endorses the l'art pour l'art principle and condemns Ekrem as decadent who disregards art for the society's sake.

The utopian individualism of the Edebiyat-ı Cedide school had indeed found a reflection in Ekrem's Bihrûz Bey as well. Bihrûz Bey, like all the other alla franca dandies, stands aloof from the Ottoman/Islamic culture. His aversion from the society in which he lives, however, is not expressed in political or social terms. Bihrûz Bey stands aloof from the Ottoman/Islamic culture in aesthetical terms and his aversion becomes a judgement of taste that condemns what belongs to that culture as ugly and praises what belongs to the Western culture as beautiful. An alla franca dandy finds, for instance, the oldfashioned konaks ('mansions') of the traditional mahalles ('neighbourhoods') an unbearable sight, whereas the Europeanized Beyoğlu district becomes a surrogate for his beloved Paris with its Neo-Classical and Neo-Gothic buildings. For Bihrûz Bey likewise, the Ottoman culture is artistically sterile, unable to produce even a single poet worthy of respect: 'Ah! There has not come a decent poet from Turks ....' ${ }^{62}$ Bihrûz Bey attributes that sterility to his very mother tongue: 'Bihrûz Bey has heard alla franca gentlemen like himself saying that there is no real poet raised from amongst Turks because there can be no poetry in Turkish. ${ }^{63}$ When Bihrûz Bey reads, for instance, an Ottoman/Turkish poem, he thus condemns it as an ugly scribble: 'What does it mean, why to bring such ugly talk into poezi? ... [poetry] Safî Bey is right: Was not he saying that there is no poezi [poetry] in Turkish and there cannot be poets among Turks? Il a rezon! [He is right]. ${ }^{64}$ Bihrûz Bey's dandyism, in this sense, manifests a profound aversion from the Ottoman/Islamic culture. There is a dichotomy of beautiful/ugly that pervades the whole novel which gives expression to Bihrûz Bey's alienation from the Ottoman/Islamic culture and to his utopian vision of Europe as an ideal to be contemplated almost as a work of art. Bihrûz Bey's aloofness from the Ottoman/Islamic culture in aesthetical terms thus detaches him from tradition and enables his personality to come to the fore in his idiosyncracy, in a manner that transforms his superficiality or his snobbish dislike for what belongs to the Ottoman/Islamic culture into a revolt in outer appearances against that culture. As it will be seen, Gürpınar's Meftûn Bey consummates that development.

\section{The individual against tradition}

Şıpsevdi is the final phase of the alla franca dandy's development before he becomes the alla franca traitor. The alla franca Meftûn Bey is a man that cannot be told apart from the other alla franca dandies in externals and condemns the Ottoman/Islamic culture through a judgement of taste like Felâtun and Bihrûz Beys. He hates the national

\footnotetext{
${ }^{61}$ Berkes, The Development, 295.

${ }^{62}$ Ekrem, Araba Sevdası, 112-3.

${ }^{63}$ Ibid., 113.

${ }^{64}$ Ibid., 118-9.
} 
literature: 'The books that he abstain from reading: Evliya Çelebi Itineraries, Turkish grammar, Ottoman literature, national novels ....'65 Indeed, Meftûn Bey carries this hatred off to greater heights: 'Not admitting that there can be an idiosyncratic Turkish originality and belittling those who claim such a thing. ${ }^{66}$ Meftûn Bey thus becomes more and more idiosyncratic in a manner that brings his individualism to the fore as his superficiality and snobbism becomes a revolt against tradition in outer appearances. However, Meftûn Bey, unlike the others, is a self-conscious personality who knows the consequences of his actions and has a world view that gives rationality to his deeds. He has views concerning the human nature, the nature of desire, sexual relations between men and women and their hypocrisy in matters of morality. He knows quite well that morality in general serves particular interests within society. In this regard, Meftûn Bey is neither a Felâtun Bey whose Westernization pertains only to social decorum nor a Bihrûz Bey whose epistemological crisis leads him to fall into many comical scenes and into a meaningless world.

Şıpsevdi's story begins as Meftûn Bey returns Istanbul from Paris. Upon his return, Meftûn Bey embarks upon the difficult task of 'educating' the members of his household in alla franca social decorum. Meftûn Bey's interest in the Western civilization does not confine itself in etiquette rules and he reads aloud European works to his household and directly endorses liberal ideas concerning, for instance, inter-sex relations. He makes plans to ensnare his neighbour Kasım Efendi, a tight fisted miser, to usurp his fortune and thinks that he might succeed in inheriting Kasım Efendi's money by marrying his daughter, who lives on borrowed time in Meftûn Bey's opinion. Meftûn Bey invites his neighbour to talk about his wish to marry his daughter and, to Meftûn Bey's surprise, Kasım Efendi accepts the proposal with the intention to get rid of his daughter's expenses. Meftûn Bey marries Kasım Efendi's daughter, though Meftûn Bey's expectation of Kasım Efendi's death comes to naught. Meftûn Bey begins to plot another plan to fleece Kasım Efendi. Meftûn Bey then picks Kasım Efendi's son up as his accomplice to steal money from Kasım Efendi's strongbox. As Meftûn Bey expects resistance to his proposal, he acclimates Kasım Bey's son to the alla franca society in Istanbul and seduces him with the help of a woman who expects a share from the theft. As they succeed in the crime, all kinds of scandals ensue and Kasım Efendi's son commits suicide. Meftûn Bey flees to Paris at once and years later sends a letter from there defending his own case against his family's accusations.

The Meftûn Bey satire is different both from the Felâtun and Bihrûz Bey satires in essentials. Meftûn Bey, unlike the other alla franca dandies, is not ridiculed himself directly as neither the Ottoman/Islamic morality's unquestionable truth nor the epistemological crisis of Westernization serve as the comedy's basis. The crisis is solved in favour of Western rationality and Şıpsevdi mocks what is irrational in society. Gürpınar says in his preface to Şısevdi that 'Some thought that I have written this novel to criticize alla francas. This is a great misinterpretation and mistake. We should distinguish between dandyism, on the one hand, and love of truth and progression in being an alla franca on the other. ${ }^{67}$ What is being mocked in Şıpsevdi is thus certainly not the aspiration for the

\footnotetext{
${ }^{65}$ Gürpınar, Şıpsevdi (Orijinal Metin) (İstanbul: Everest Yayınları, 2008), 58. All the translations from this novel are mine. ${ }^{66}$ Gürpınar, Şıpsevdi, 59.

${ }^{67}$ Gürpınar, Şıpsevdi, 3.
} 
European culture with its rationalism, but an inability to do so. This inability might be caused by the stifling morals of the Ottoman/Islamic culture or by snobbism. Gürpınar is quite unambigious in this regard: 'The Western civilization has become a torch of awakening for us. From now on, it will be our leader in progress as well.' He even claims that 'We learned to think, to write novels, and the love of liberty from them'. Reflecting Gürpınar's attitude, Meftûn Bey plays a double role; sometimes an irrational aesthete enamoured of the European culture's façade and sometimes a cynic that seeks the truth about society's moral values and derides their folly. Gürpınar says:

Is Meftûn a madman who is taken ill by the illness of being a francophile? No. As we will see, this is not the case either ... It is a more reasonable idea that he is unstable in his mind, as he has moments when he shows a sound reason, as in the case of malaria attacks. ${ }^{68}$

When Meftûn Bey 'shows a sound reason', he becomes Gürpınar's mouthpiece in disguise and endorses the European ideals of liberty and rationalism.

Irrationality and the hypocritical morals of society are the two faces of the same coin. Though Kasım Efendi's conservative daughter (i.e. Meftûn Bey's wife) condemns Meftûn Bey's Westernized family as immoral, she herself falls into the very same errors and begins to have love affairs in her husband's absence. To throw off the yoke that stifles men and women, reason has to be held in the highest esteem. When, for instance, Meftûn Bey witnesses his lackey and cook-woman as they have sex, he contrasts the rationality in nature with the irrational, hypocritical morals and traditions:

Nature is such an effective force that it subjugates all to its laws. Who are now carousing, talking, exclaiming, yelling, dancing, making love, kissing each other here are not Zarafet and Şaban, but that natural force itself. As Schopenhauer has said, in the bodies, veins and blood of these lovers there are the seeds of generations of the mankind. [...] This is the whole truth which people call, poetically or vulgarly, 'debauchery,' 'womanizing,' 'love,' and many other names. [...] Whatever the ethical philosophers say, this force that makes Şaban and Zarafet to fall in love with each other and compels them to such frenzies is sovereign in the world despite the counsels of pedants. [...] He who strives to oppose the laws of nature is exhausted in vain. ${ }^{69}$

Meftûn Bey, when he thus acts as Gürpınar's mouthpiece, questions, criticizes and reevaluates the Ottoman/Islamic values and tradition through rationalism and paves the way for the individual's emergence who will be in liberty.

In his letter from Paris, Meftûn Bey might be said to have written a manifesto of the individual's value against tradition that has become a source of corruption as it rests on hypocrisy and irrationality:

Greetings brother!

[...] Are you still cursing me, from the moment we departed to this day? You are being unjust to me ... You have not understood human beings and humanity properly ... Those who do not take pains in the pursuit of that great truth, who do not gain such difficult verities of life through bitter experiences, who bring forth some groundless ideas of lofty morals, slowly become mournful, and disturbed throughout their lives as the emptiness of their assumptions and hopes come to light. To understand the truth, to cast off vain hopes ... This is sagacity. Beyond that it is all hamartia and foolishness. The flocks of mankind are

${ }^{68}$ Ibid., 13.

${ }^{69}$ Ibid., $193-4$. 
always the victim of that hamartia and foolishness. Here it is the key for life's theory! [...] A man always passionately tries to tread the weak under foot to reach the upper-strata. That false justice of the mankind is concocted to keep the fools in subjection. [...] In this world, egotism reigns before everything else. Everyone acts according to his egotism. As one individual's egotistic acts will clash with another's same intentions, there emerges the need to establish justice and laws. [At this point, Meftûn Bey quotes a 'German philosopher,' possibly a blend of Gürpınar's ideas that he derived from Schopenhauer and Nietzsche on morality, egoism, and the human nature.] Both of us are men who succumb to their egotism, as the philosopher has described. You seem to believe in lofty morality, and deceive yourself as you strive to see yourself to belong to that coterie. I, on the other hand, show myself as I am, my nature as a human being, without fear and garnish. Who is right, then? [...]

Your brother Meftûn ${ }^{70}$

As Meftûn Bey's brother Raci reads the letter, he hands it over to his sister Lebibe Hanım and says:

As I was reading the letter I thought that I am sitting face-to-face with my brother Meftûn ... That philosophy, that reason, and these ideas again ... He has not changed. One of the ancient sages says that he has learnt morality from immoral men ... We, on the other hand, learn morals from him. Owing to him, we learn the truths of life and of philosophy in their various manifestations. ${ }^{71}$

As his family forgives him, the alla franca Meftûn Bey's ideas and manner of life do not appear any more to be an example of Westernization gone astray or a crisis of identity. His ideas begin to reflect rather the truth that one is always an egoist and should act accordingly without moral scruples that indeed serve the society's, or other individuals' interests. Meftûn Bey, in this manner and as a self-conscious character, dares to criticize openly the social institutions and morals of the society. Meftûn Bey even seems to be conscious of his critical stance that acts in a destructive manner when he names himself a nihilist:

May I tell you what I am? I am such a thing that my philosophy will be in demand only a century later. As decadism and symbolism fade away, from their farthest lights, another philosophy will glisten. Do you know what it will be called? Let me give a name to it by mixing Turkish and French ... Sir, it will be called 'hiçizm' [nihilism]. Because, a sick man tries to cure himself ... Why? To become sick again and die after a while ... What drags people from a folly to another is their fatuity in understanding this nothingness. ${ }^{72}$

Meftûn Bey's hiçizm, that is, his nihilism should be seen as a weariness, a nausea in the face of social reality that he wants to topple down to make room for an alternative future in which the individual would be in liberty. It is worth noting that Meftûn Bey's hiçizm has a certain similarity of meaning with some avant-gardist ideas and principles. Within Russian futurism, for instance, a group of artists had called themselves 'nichevoki', that is, 'the nothing-ists', a word that resonates well with hiçizm. Such 'nothingism', indeed, is a general attitude that was shared by many modern, avant-garde art movements. Renato Poggioli says that the avant-gardist artist '[...] finds joy not merely in the

\footnotetext{
${ }^{70}$ lbid., 468-73.

${ }^{71}$ Ibid., 474.

${ }^{72}$ Ibid., 61-62.
} 
inebriation of movement, but even more in the act of beating down barriers, razing obstacles, destroying whatever stands in its way'. ${ }^{73}$ Poggioli defines that attitude as 'nihilism', or 'the nihilistic moment', in which the artist provokes, scandalizes and assaults on the society's cultural norms and moral principles for the sake of that antagonism itself. Through such an activism, the avant-gardist artist believes that from the ruins of the society's corrupt state, there would emerge a future that is much more desirable, though the artists themselves do not have a concrete consciousness of what that future would be like.

The alla franca Meftûn Bey is thus a man in whom the condemnation of the Ottoman/ Islamic culture through a judgement of taste, an idealization of the European culture's rationalism and the emergence of the individual in his liberty coincide. He is the true utopian individual for whom the European culture becomes a work of art in its luminosity. Gürpınar, with his Meftûn Bey, puts the individual against the society and individual per se thus becomes a reference point to re-evaluate value judgements of the Ottoman society. Gürpınar's Meftûn Bey, in this regard, completes the alla franca dandy's development that culminates in an awareness of the individual's importance in a modernizing society.

\section{Conclusion}

The alla franca dandy's development as the birth of individualism is important to understand the Ottoman modernization. Recent literature on modernity has increasingly concentrated on the possibility of 'co-eval' time in which alternative or multiple modernities, based not on a linear time but on local experiences and adaptations, are possible. In this regard, Göle's contributions to the decentring of the West and her conception of 'extra modernity' is of much value. ${ }^{74}$ Such a stance, which I share, argues that each culture inescapably gravitates towards forms of modernity, but shaped under different historical trajectories: "To think in terms of "alternative modernities" is to admit that modernity is inescapable and to desist from speculations about the end of modernity. ${ }^{75}$ What makes all these different experiences 'modern' is a trend towards what might be called a problematizing of the present as something deficient and in need of intervention to transgress the current conditions and to reach an ideal state of affairs in the future; $a$ process in which the individual plays a prominent role. As the present of a society is questioned and deemed to be deficient, such problematizing finds reflection in the individual's relation to that very same present and to oneself, as in Foucault's interpretation of Baudelaire's vision of modernism as dandyism, ${ }^{76}$ in which one takes oneself to be an object of anxious, ascetic elaboration in the vacuum opened up by the disintegrating traditions of a problematical present. It may even be argued that what appears to be snobbism in any modernization might be the symptoms for a modernity taking roots. As George Simmel says of the dandy's unique individuality: 'He leads the way, but all travel

\footnotetext{
${ }^{73}$ Renato Poggioli, The Theory of the Avant-Garde (Cambridge: The Belknap Press of Harvard University Press, 1968$), 62$.

${ }^{74}$ Nilüfer Göle, 'Global Expectations, Local Experiences: Non-Western Modernities', in Through a Glass, Darkly: Blurred Images of Cultural Tradition and Modernity Over Distance and Time, ed. Wil Arts (Leiden: Brill, 2000), 40-55.

${ }^{75}$ Dilip Parameshwar Gaonkar, 'On Alternative Modernities', in Alternative Modernities, ed. Dilip Parameshwar Gaonkar (North Carolina: Duke University Press, 2001), 1.

${ }^{76}$ Michel Foucault, 'What is Enlightenment?' in The Politics of Truth, ed. by Sylvère Lotringer (California: Semiotext(e), 2007), 108.
} 
the same road. Representing as he does the most recently conquered heights of public taste, he seems to be marching at the head of the general procession. ${ }^{77}$ Nurdan Gürbilek's extraordinarily perceptive views of Turkish modernity as snobbism should be repeated at this point. Gürbilek, concerning Araba Sevdası, says that:

[...] The Carriage Affair is a significant work since it has drawn the irreversible line in the Turkish novel, pointing out that snobbism is the constitutive element of the 'original Turkish spirit' itself, where not only gestures and appearances but the inner world itself is at stake. If there is a weakness in the modern Turkish novel, it is not because it has not returned to an original self, but because it has not faced the inevitable lack of originality, the fact that it is always too late to return to an original self.

Superficiality, thus, should not be taken superficially.

In the late 19th-century Ottoman society, the roots of modernity and individualism were not in capitalistic development as is was the case for European societies, and only partly in secularization. In European history and thought, individualism and liberty are conceptually inseparable. Negatively, liberty is the lack of interference by others as individuals act and, positively, the realization of one's ideal self. ${ }^{78}$ In such broad terms, individualism may be said to emerge in a similar fashion across different cultures and times. Yet, as I have argued, modernity (and, for that matter, individualism) has different forms. What distinguishes the late 19th-century Ottoman individualism was a profound sense of dissatisfaction with the present and also a utopian vision; a vision that offered a flight from the social and political realities of the Hamidian period's autocracy. Such retreat into the inner citadel resulted in the idealization of the Western culture through aesthetical terms as a non-political, non-ideological construct in its autonomy and thus become a seduction. It was a seductive vision by means of which modernization infiltrated more freely into the Ottoman/Islamic culture as it appeared non-political. The alla franca dandy figure, in this regard, was an expression of a judgement of taste that condemned the Ottoman/Islamic culture as ugly before the beauties of the Western culture, thus eroding the traditional values and filling up the vacuum created by that erosion with the autonomous, utopian individual in her/his liberty. As Gregory Jusdanis says in relation to Greek modernization and the role of Greekness as the symbol of an integrating, harmonious experience: 'When culture ceases being visible, no longer a construct to be fought over but an ideology concealing its operations, it functions aesthetically. ${ }^{79}$ The West is a Trojan horse that functioned as a culturally modernizing force in the Ottoman/Turkish modernization. ${ }^{80}$ The alla franca dandies of the Ottoman novel, as figures best recognized by their aloofness from the Ottoman culture in aesthetical terms, express this aesthetical admiration of the West seen as a way out. As Niyazi Berkes says: 'The Westernists' admiration for the Western civilization was similar to the love of a sensitive youth for a beautiful, unknown woman. ${ }^{81}$ This aesthetical attitude, I argue, has opened up a way to a unique modernist stance, though

\footnotetext{
${ }^{77}$ Georg Simmel, On Individuality and Social Forms (Chicago: The University of Chicago Press, 1971), 305.

${ }^{78}$ Isaiah Berlin, Liberty (Oxford: Oxford University Press, 2002), 166-217.

${ }^{79}$ Gregory Jusdanis, Belated Modernity and Aesthetic Culture: Inventing National Literature (Minneapolis: University of Minnesota Press, 1991), 81-82.

${ }^{80}$ I owe this analogy to Göle. See: Göle, Modern Mahrem, 94.

${ }^{81}$ Berkes, The Development, 297.
} 
different from its European counterparts, and created possibilities for individual selfexpression in consequence, a development that is reflected in the alla franca dandy figure's utopianism.

\section{Disclosure statement}

No potential conflict of interest was reported by the author.

\section{ORCID}

Korhan Mühürcüoğlu (D) http://orcid.org/0000-0002-7526-3927 